\title{
ZEOLITES IN TECHNOLOGIES OF POLLUTION PREVENTION AND REMEDIATION OF AOUUATC SYSTEMS
}

\author{
O. B. Kotova ${ }^{1}$, M. Harja ${ }^{2}$, I. Cretescu ${ }^{2}$, F. Noli ${ }^{3}$, Y. Pelovski ${ }^{4}$, D. A. Shushkov ${ }^{1}$ \\ ${ }^{1}$ Institute of Geology Komi SC UB RAS, Syktyvkar, Russia, kotova@geo.komisc.ru \\ $2_{2}$ Gheorghe Asachi» Technical University of Iasi, Iasi, Romania, mharja@tuiasi.ro; icre@tuiasi.ro \\ ${ }^{3}$ Aristotle University, Thessaloniki, Greece, noli@chem.auth.gr \\ ${ }^{4}$ University of Chemical Technology and Metallurgy, Sofia, Bulgaria, yonchop@gmail.com
}

The efforts of applied mineralogists and chemists are combined to produce sorbents that are competitive in the world market. Modern methods were used to study the physical and chemical (technological) properties of natural sorbents. We observed the technologies of modification of analcime-bearing rocks to increase the efficiency of pollution prevention and remediation of aquatic systems. We presented a comparative evaluation of sorption-filtering properties of analcime-bearing rocks and quartz sand to improve the process of purification of drinking and waste water from various types of pollution.

Keywords: natural sorbents, aquation systems, analcime-bearing rocks, quartz sand, physical and chemical properties.

\section{ЦЕОЛИТЫ В ТЕХНОЛОГИЯХ ПРЕДОТВРАЩЕНИЯ И ВОССТАНОВЛЕНИЯ ВОДНЫХ СИСТЕМ ОТ ЗАГРЯЗНЕНИЯ}

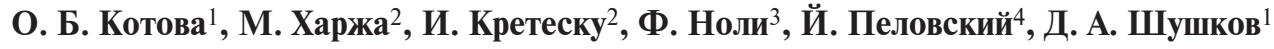 \\ ${ }^{1}$ Институт геологии Коми НЦ УрО РАН, Сыктывкар, Россия \\ ${ }^{2}$ Технический университет им. Г. Асаки, Яссы, Румыния \\ ${ }^{3}$ Университет им. Аристотеля, Салоники, Греция \\ ${ }^{4}$ Университет химической технологии и металлургии, София, Болгария
}

\begin{abstract}
Объединены усилия прикладных минералогов и химиков для получения сорбентов, конкурентоспособных на мировом рынке. При исследовании физико-химических (технологических) свойств природных сорбентов использовались современные методы. Рассмотрены технологии модифицирования анальцимсодержащих пород для повышения эффективности предотвращения и восстановления водных систем от загрязнения. Дана сравнительная оценка сорбционно-фильтрующих свойств анальцимсодержащих пород и кварцевого песка для усовершенствования процесса очистки питьевых и сточных вод от загрязнений различного типа.
\end{abstract}

Ключевые слова: природные сорбенты, водные системы, анальцимсодержащие породы, кварцевый песок, физические и химические свойства.

\section{Introduction}

Prevention of pollution and remediation of water systems is one of the global problems of our civilization. The Earth has huge resources and remediation mechanisms for water purification in nature. A human being needs to study and use these mechanisms. Therefore natural sorbents are involved in the technologies of water purification from various pollutions. Natural minerals are affordable and low-cost, have a possibility of a single use, as a rule, they possess an increased selectivity to toxic elements, are resistant to ionizing radiation and a number of other advantages. A high level of modern experimental technologies allows obtaining practically any synthetic material, but the question of the priority (expediency) of using natural mineral raw or synthetic materials is always important. Such discussions have been going on for a long time, for example, about zeolites. As a rule, synthetic material is produced as a result of expensive technologies and rather harmful chemical reagents. At the same time natural mineral raw (zeolites, montmorillonites, opals, etc.) with insignificant and inexpensive modification of their physical and chemical properties can serve as an excellent basis for competitive materials. Since Russia, Romania, Greece and other countries entered the world market, the requirements to both technological and environmental parameters of the products increased. All these facts call for, firstly, profound knowledge on minerals, as carriers of necessary chemical elements and useful properties, features of their real crystal structure; secondly, understanding the mechanisms of changes in the parameters of minerals un- der the influence of natural and technogenic impacts; thirdly, understanding the mechanisms of the improvement of the properties of sorbents, various methods of modification are required, including technologies for sorbent synthesis based on mineral raw and products of their processing; fourthly, combining the efforts of applied mineralogists and chemists to produce sorbents that are competitive in the world market.

A wide application of natural zeolites and zeolite-bearing rocks in the environmental protection is conditioned by their adsorption and ion-exchange properties. They acquire the greatest practical importance as adsorbents for removal of harmful components from gas emissions of chemical, petrochemical industries and non-ferrous metallurgy, as well as for the purification of industrial waste waters from heavy metals, oil products, phenol, radioactive elements and domestic sewage from ammonium $[3,7,9,10]$.

At present the urgency of the problems associated with the purification of drinking and household waters is not in doubt. The most common sorbent for deep cleaning of household and drinking water is activated carbon - granular and powder, as well as quartz sand, clay, expanded clay. At the same time quartz sand does not possess sorption properties for organic substances and heavy metals. The sorption properties of activated coal are expressed only for organic pollutants, and their widespread application is in practice constrained by high costs and deficit. Apart from activated carbons, natural zeolites also possess sorption properties. These properties of zeolites are expressed not only for organic impurities, imparting 
tastes and smells to the water, but also for heavy metals and radionuclides.

Objective: Comparative evaluation of sorption-filtering properties of analcime rocks and quartz sand for improving the process of purification of drinking and waste water from various types of contamination and studing of methods of analcime-bearing rocks modification in order to increase its sorption and cation exchange parameters.

\section{Objects and methods}

Analcime-bearing rocks of the Veslyana group occurrences (Koinskaya zeolite area, Timan Region) are represented by Upper Permian aleurolites and argillites, less often by marls. The analysis of the mineral composition showed that the rocks are characterized by a high clay content (50$70 \%)$ impregnated with iron oxides and hydroxides, also quartz (10-30\%), analcime (1-30\%), feldspars (2-10\%), carbonates $(2-5 \%)$ are present. The clay minerals are represented by a disordered, mainly swelling, mixed phase (illitesmectite, illite-chlorite), kaolinite and chlorite are present insignificantly. A detailed description of these rocks is presented in [8].

Quartz sand - a crushed mineral with a high content of quartz (up to $98 \%$ ), as a filler for water filters [2], which specifies the requirements for filtering granular materials in the treatment of drinking and household water.

Experiments on drinking water purification with analcime-bearing rocks and quartz sand were carried out as follows: in 2 columns with a volume $300 \mathrm{ml}$, a filtering load with a layer height $0.22 \mathrm{~m}$ was placed. The initial water, taken from the sampler of Vychegda River, was poured through the funnels. The contact time of the initial water with the filtering load was 15 minutes, and then filtration was started at a rate $5.4 \mathrm{~m} / \mathrm{s}$. The filtered water was collected in flasks with a volume $0.9-1.0 \mathrm{dm}^{3}$ every $2-3$ hours and the color, turbidity, $\mathrm{pH}$, iron content and permanganate oxidability were determined. The comparison of analcime rocks to quartz sand, and not to other sorbents, for example zeolites, was carried out because currently quartz sand is used at a local water treatment plant. When using analcime rocks without any treatment, the permanganate oxidability increased from 3.77 to $9.49 \mathrm{mg} /$ $\mathrm{dm}^{3}$. Therefore, further studies were carried out on a modified analcime rocks obtained by calcination at a temperature of $600{ }^{\circ} \mathrm{C}$ for 1 hour. The heat treatment allowed to remove organic substances from analcime-bearing rocks and to increase their sorption properties.

The cation exchange capacity for barium was measured by the Bobko-Askinazi-Aleshin method according to GOST 17.4.4.01-84 [1]. The sorption structural parameters (specific surface area, micro- and mesopore volume, total pore volume) were determined using an analyzer of surface area and pore size NOVA 1200e, Quantachrome. The specific surface area was calculated by the BET method (nitrogen adsorption curve), the mesopore volume by the BJH method (nitrogen desorption curve), the micropore volume by the DubininAstakhov method.

The heat treatment of the samples was carried out in a muffle furnace in the temperature range from 100 to $900{ }^{\circ} \mathrm{C}$ with steps by $100{ }^{\circ} \mathrm{C}$ for 1 hour, then the samples were cooled in a desiccator. Mechanical activation was carried out in a bowl attritor, the duration of the grinding was from 20 seconds to 20 minutes. Acid activation was carried out with 5, 10 and 20 percent solutions of hydrochloric, sulfuric and nitric acids for 1 hour.

\section{Results and discussion}

Analcime-bearing rocks and quartz sand approximately equally improved organoleptic parameters of water quality: chromaticity decreases by $15 \%$, turbidity - by 4.7 times (fig. 1,2). However, the analcime-bearing rocks significantly reduced the iron content in water (by 3.7 and 2.5 times, respectively) and reduces the permanganate oxidability (by 20 and $1 \%$ respectively) (fig. 3,4$)$. pH parameter slightly increased from 7.23 till 7.6 in both cases. The results of the researches in this area are brought to the patent [6].

The high efficiency of wastewater treatment of «Vylgortskaya sapogovalnaya fabrika» with analcime-bearing rocks was established. When filtering wastewater through the column, a significant decrease was found in the following indices: suspended matter, turbidity, chemical oxygen demand, ammonium, petroleum products, phosphates. In addition the water $\mathrm{pH}$ increase from acid (4.57) to neutral (7.3) was noted. At the same time no decrease of the concentration of sulphates and chlorine in the filtered water was detected.

Analcime-bearing rocks were used for the post-treatment of sewage waters from the boiler plants from chlorine, iron, ammonium nitrogen, phosphates, petroleum products, heavy

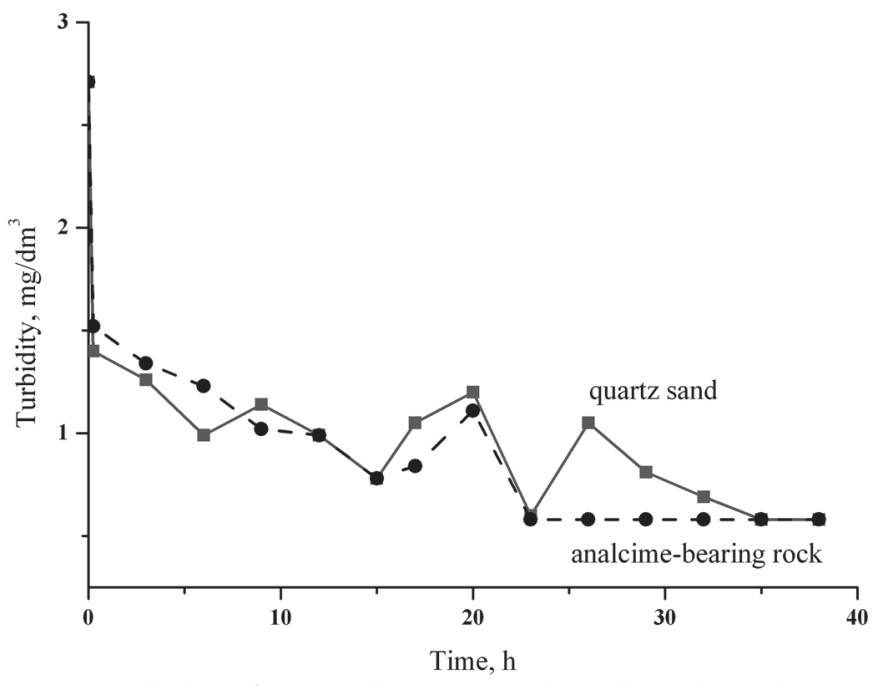

Fig. 1. Turbidity of water when passing through analcime-bearing rocks and quartz sand

Рис. 1. Мутность воды при пропускании через анальцимсодержашую породу и кварцевый песок

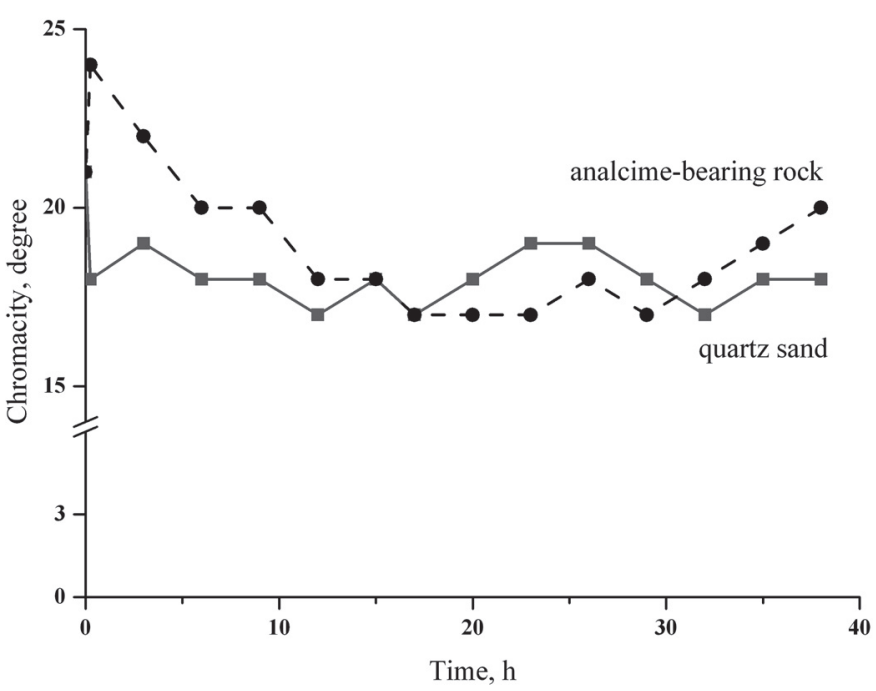

Fig. 2. Chromacity when passing through analcime-bearing rocks and quartz sand

Рис. 2. Цветность воды при пропускании через анальцимсодержащую породу и кварцевый песок 


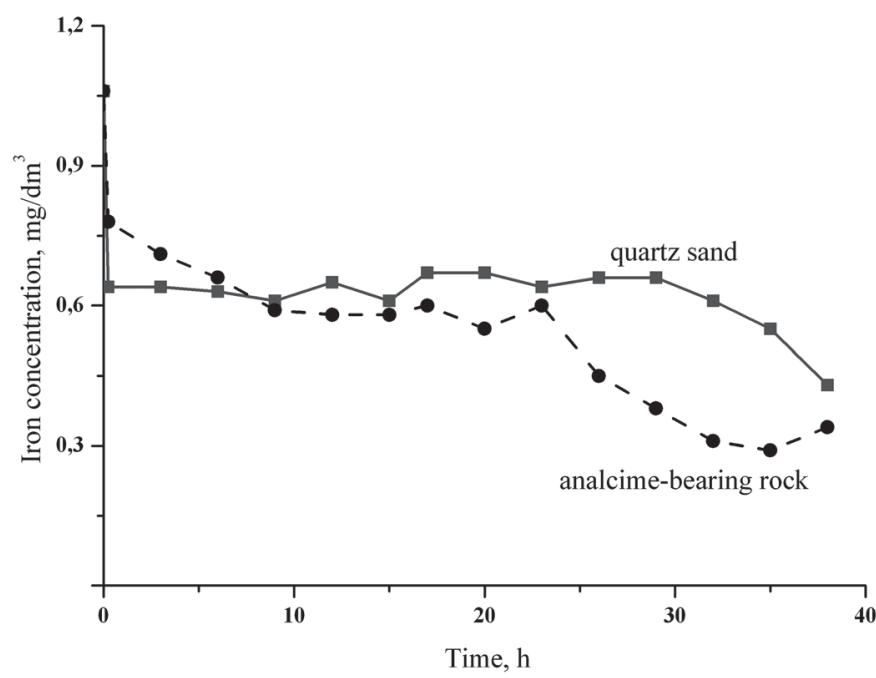

Fig. 3. Iron concentration when passed through analcime-bearing rocks and quartz sand

Рис. 3. Содержание железа в воде при пропускании через анальцимсодержащую породу и кварцевый песок

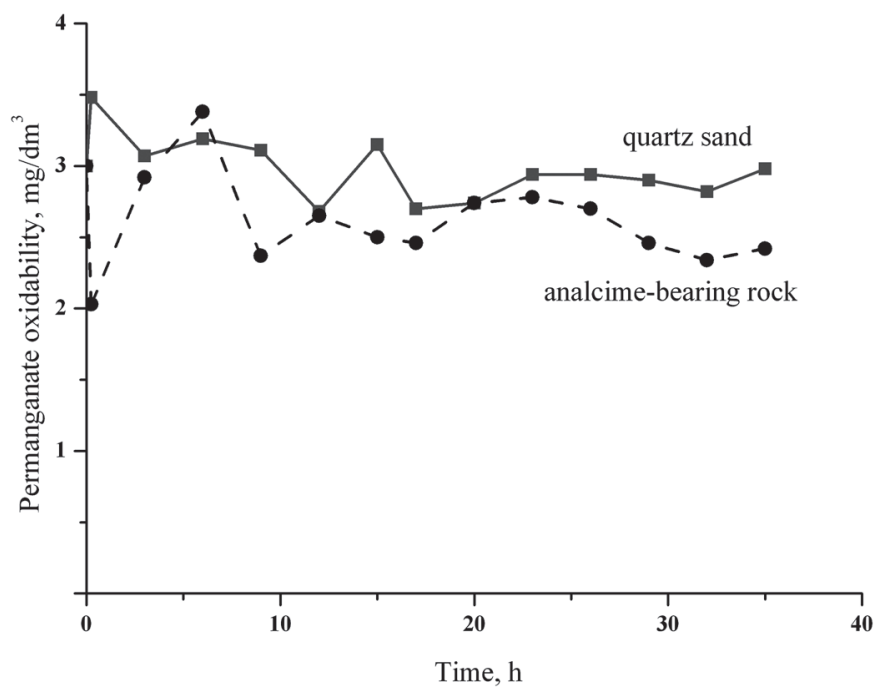

Fig. 4. Permanganate oxidability when passing through analcimebearing rocks and quartz sand

Рис. 4. Перманганатная окисляемость при пропускании через анальцимсодержащую породу и кварцевый песок

metals, suspended matter [4]. The sorption capacity of iron ions (0.13 mg-equiv/100 g), amines (10 mg-equiv/100 g), magnesium (5.94 mg-equiv/100 g), phosphates (1.42 mg-equiv/100 g) were determined. Sufficiently high adsorption properties with respect to petroleum products and PVA were assumed. It was determined that purification of waters with the help of analcime-bearing rocks was quite effective in many parameters. As a result of researches it was considered that a technological scheme using analcime-bearing rocks as a granular filter load and a membrane device for desalting industrial water is the most rational scheme. Preliminary a high efficiency of analcime-bearing rocks as a sorbent for the elimination of accidents with oil spills was determined [5].

To determine the most promising directions of application of analcime-bearing rocks, it is very important to study their physical and chemical (technological) properties and the possibility of directional change of the properties by various methods of influence.

As main studied parameters we chose a cation exchange capacity (CEC) and a specific surface area (SSA). In addition to the specific surface, we estimated other structural parame- ters: the volume of micro- and mesopores and the average radius of the pores. The changes in these parameters were studied as a result of various methods of influence: thermal, mechanical and acidic.

Starting CEC of analcime-bearing rocks varies in the range from 18.7 to $53.2 \mathrm{mg}$-equiv/100 g; CEC of analcime was $21.5 \mathrm{mg}$-equiv/100 g. The dependence of the exchange capacity on the analcime content in the rocks was not revealed.

Starting SSA of analcime-bearing rocks varies in the range from 9.1 to $45.4 \mathrm{~m}^{2} / \mathrm{g}$, SSA of analcime is $1.5 \mathrm{~m}^{2} / \mathrm{g}$. This is due to the fact that the diameter of the channels of analcime $(0.26$ and $0.16 \times 0.42 \mathrm{~nm})$ is smaller than the diameter of the nitrogen molecule $(0.32-0.35 \mathrm{~nm})$. Therefore, in this case, we cannot measure SSA of analcime, and the resulting surface is determined by the content of clay minerals.

Thermal activation. To measure SSA it is necessary to empty the pores, i. e. to remove water, $\mathrm{OH}$ groups and other volatile compounds, but so that crystal lattice of the sample is not destroyed. We studied the dynamics of the change of SSA during thermal treatment within 100 to $900{ }^{\circ} \mathrm{C}$. As seen on the fig. 5, SSA initially increases with increasing processing temperature, reaching a maximum value at $450{ }^{\circ} \mathrm{C}$. Here, the value of SSA increases by almost 2 times compared to the starting one. With further increase in temperature, it begins to de-

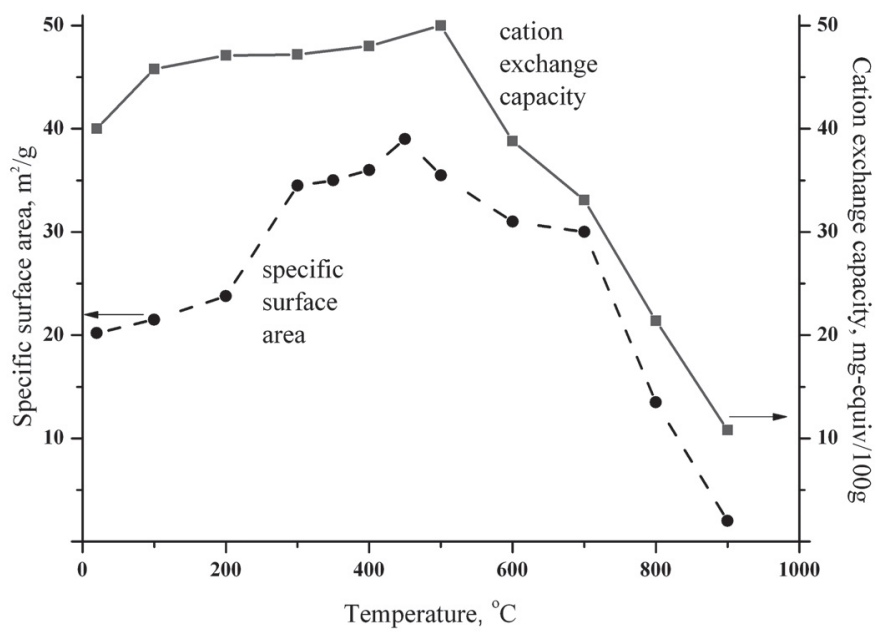

Fig. 5. Depending of specific surface area and cation exchange capacity on temperature of calcinations

Рис. 5. Зависимость удельной площади поверхности и катионообменной емкости от температуры прокаливания

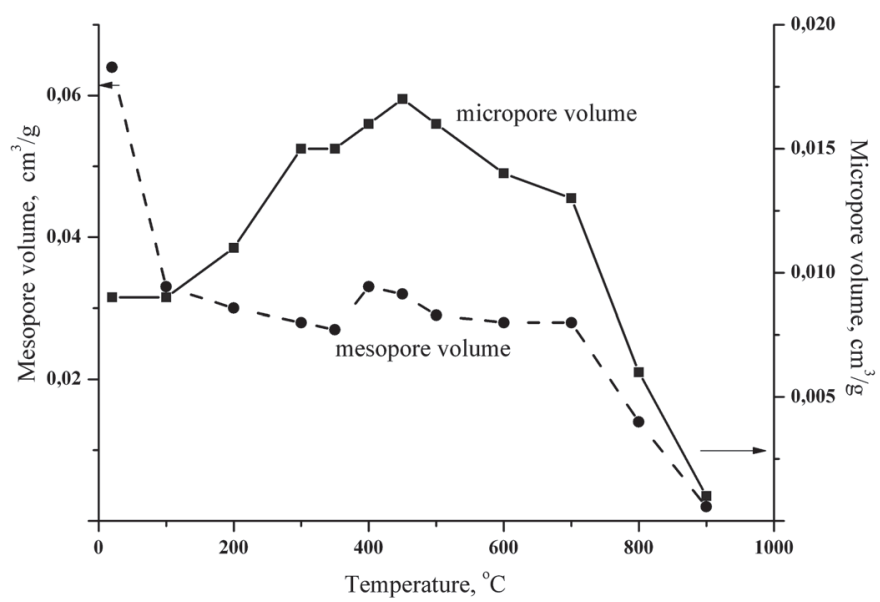

Fig. 6. Depending of micropore and mesopore volume on temperature of calcinations

Рис. 6. Зависимость объема микро- и мезопор от температуры прокаливания 
crease and, after annealing at $700{ }^{\circ} \mathrm{C}$, drops sharply to almost 0 . The average pore radius first slightly increases and then remains practically unchanged with a value $2.5 \mathrm{~nm}$ and only at annealing at $900{ }^{\circ} \mathrm{C}$. As for the volume of micropores, a correlation with SSA is observed (fig. 6). The volume of mesopores at $100{ }^{\circ} \mathrm{C}$ heat treatment decreases by 2 times, then oscillates around $0.03 \mathrm{~cm}^{3} / \mathrm{g}$, and after $700{ }^{\circ} \mathrm{C}$ it decreases sharply. CEC gradually increases with heating, at $500{ }^{\circ} \mathrm{C}$ it is higher than the starting one by $25 \%$ (fig. 5). At further annealing, CEC is also significantly reduced.

Most likely the increase of SSA and CEC are associated with the removal of the structural water of analcime and clay minerals. With further heating crystal lattice of analcime and clay minerals are destroyed, so the studied parameters are reduced.

Mechanical activation. As seen on the fig. 7, 8, in the beginning, when the grinding time is increased, SSA also increases and reaches its maximum value within 2 minutes, increasing almost by 1.5 times. Further, when the time of the grinding is increased, SSA value decreases, with grinding for 20 minutes SSA is almost half the starting one. The average radius of the pores practically does not deviate from the value of $2.25 \mathrm{~nm}$. The volume of micro- and mesopores also gradually increases, reaching its maximum with a duration 2 minutes, and then decreases.

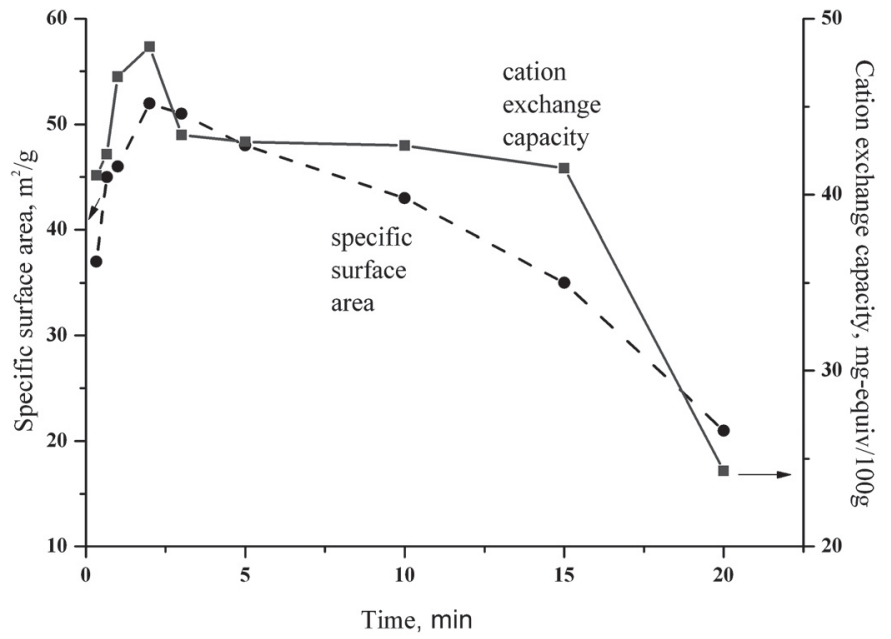

Fig. 7. Depending of specific surface area and cation exchange capacity on time of grinding

Рис. 7. Зависимость удельной площади поверхности и катионообменной емкости от времени истирания

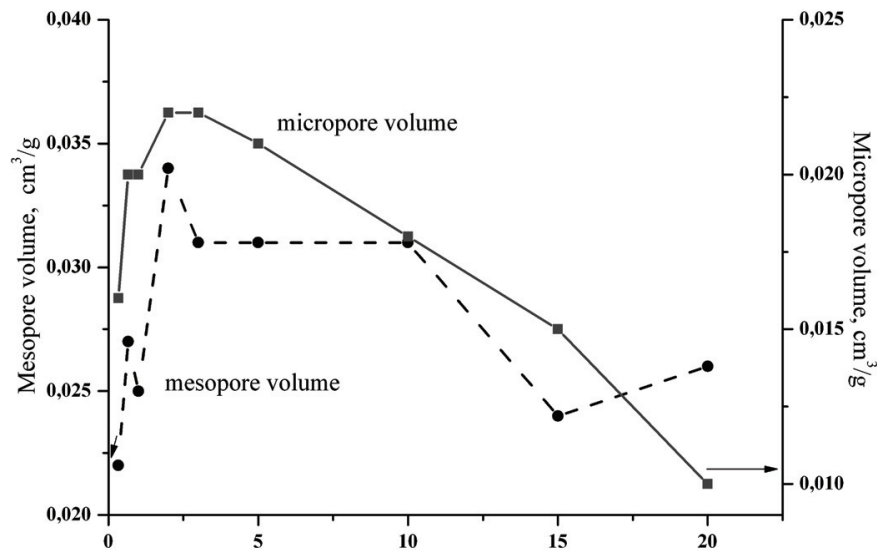

Fig. 8. Depending of micropore and mesopore volume on time of grinding

Рис. 8. Зависимость объема микро- и мезопор от времени истирания
Concerning CEC, the same effect is observed here: CEC increases to duration of 2 minutes (by $18 \%$ ), then decreases, and for some time it does not change, and only at 20 minutes of grinding the value of CEC strongly decreases.

Acid activation. Another way to improve the sorption and ion-exchange properties is acid activation. We performed the activation by 5,10 and 20 percent solutions of hydrochloric, sulfuric and nitric acids. In all the cases we observed an increase of SSA (fig. 9). When treated with $5 \%$ and $10 \%$ hydrochloric acid, SSA increases by factors of 2 and 3 respectively. Exposure to a more concentrated acid results in a reduction of SSA. When treating with 5 and $10 \%$ sulfuric acid, SSA increases at 2 times, while processing $20 \%$ - it decreases. Under the influence of $5 \%$ nitric acid, the surface is also doubled, the treatment with 10 and $20 \%$ solutions of nitric acid results in a decrease of SSA. Probably, the increase of the acid concentration is associated with the destruction of clay minerals and, as a consequence, a decrease of SSA.

Practically after all the experiments the CEC increase is observed (fig. 10). We determined that the treatment with hy-

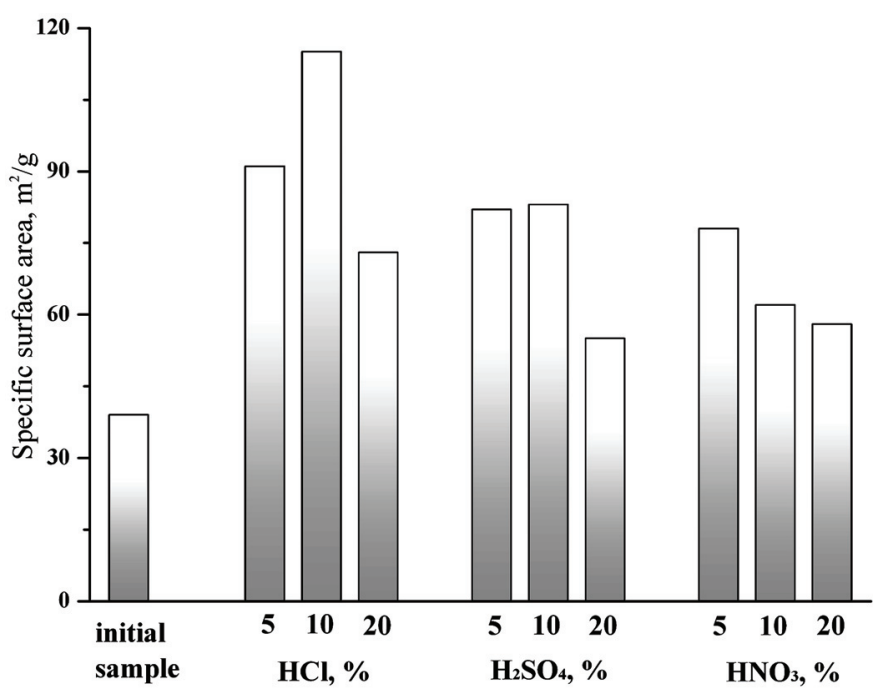

Fig. 9. Specific surface area of initial sample and acid processed samples

Рис. 9. Удельная площадь поверхности исходного и обработанных кислотами образцов

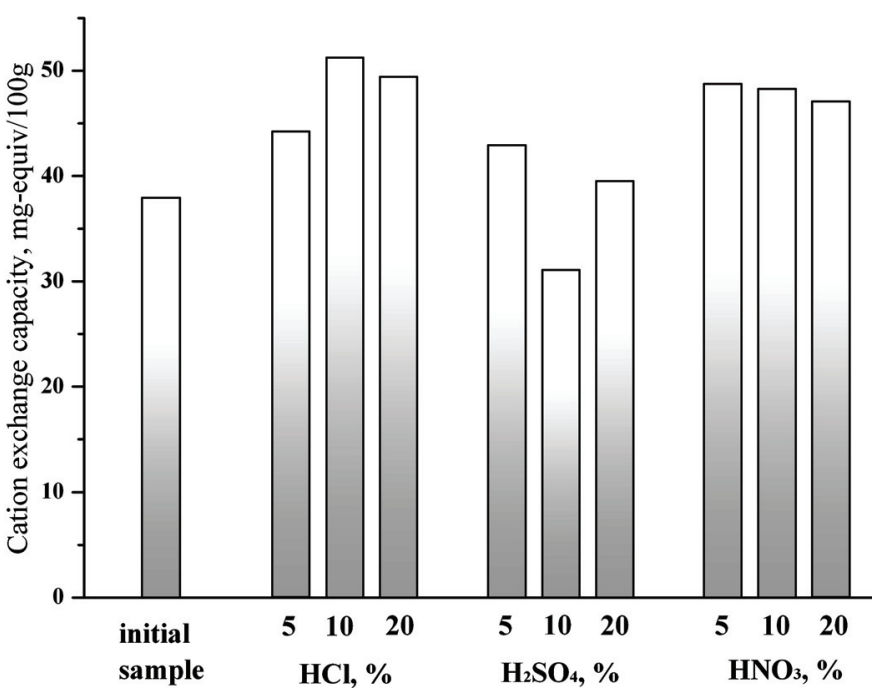

Fig. 10. Cation exchange capacity of initial sample and acid processed samples

Рис. 10. Катионообменная емкость исходного и обработанных кислотами образцов 
drochloric acid results in the increase of CEC by $30-35 \%$, nitric acid by $24-28 \%$. The activation by sulfuric acid increases CEC by only $4-13 \%$.

\section{Conclusion}

Thus, after various methods of influence (thermal, mechanical and acid), we observed the improvement of sorption and cation-exchange properties of analcime-bearing rocks of the Timan Region.

At thermal treatment within 100 to $900{ }^{\circ} \mathrm{C}$ the optimal temperature for these rocks is the annealing temperature 450 $500{ }^{\circ} \mathrm{C}$, at which the specific surface area and exchange capacity increases by 1.9 and 1.25 times, respectively. At a further increase of the temperature, the studied parameters decrease significantly.

Mechanical activation experiments, lasting from $20 \mathrm{sec}-$ onds to 20 minutes, showed that the optimum grinding time is 2 minutes and resulting in the increase of the specific surface area by 1.5 times and the exchange capacity by 1.2 times. The grinding, lasting more than two minutes, results in the decrease of these parameters.

The most efficient method is a treatment with acid solutions (hydrochloric, sulfuric, nitric). The treatment with $5 \%$ and $10 \%$ hydrochloric acid results in increasing specific surface area by 2 and 3 times respectively, and the cation exchange capacity by $1.3-1.35$ times. More concentrated acids result in the decrease of the parameters.

Based on the obtained results it should be noted that according to its characteristics, analcime-bearing rocks can be used as filter material for cleaning household and drinking waters in fast filters at water intakes instead of quartz sand.

Acknowledgements. The reported study was funded by the Uralian Branch of RAS Grant № 15-11-5-33. The authors express gratitude to the common use center «Geonauka» for their help in analytical work.

\section{References}

1. GOST 17.4.4.01-84. Nature protection. Soils. Methods for determining the capacity of cation exchange. (in Russian)

2. GOST R 51641-2000 Filtering granular materials. (in Russian)

3. Kotova O. B., Shabalin I. L., Shushkov D. A., Ponaryadov A. V. Sorbents based on mineral and industrial materials for radioactive wastes immobilization // Vestnik of Insitute of Geology of Komi SC of UB of RAS. 2015. № 2. C. 32-34.

4. Lanina T. D., Varfolomeev B. G. Use of natural zeolite for post-treatment of sewage waters from the boilers of the Vuktyl gas field // Construction of oil and gas wells on land and at sea. 2007. № 8. Pp. 38-40. (in Russian).

5. Lanina T. D., Varfolomeev B. G., Gezhberg Yu. M. Use of natural materials for oil-containig slags purification // Environment protection in oil and gas industry. 2005. № 11. Pp. 20-22. (in Russian).

6. Patent № 2296718 RU. The method of water purification / D. A. Shushkov, O. B. Kotova, I. P. Palshin. 10.04.2007, bull. № 10. (in Russian).

7. Hatkova A. N., Razmakhnin K. K. Zeolite-containing rocks of Eastern Transbaikalia: new technologies of processing // Vestnik of Insitute of Geology of Komi SC of UB of RAS. 2016. № 1. Pp. 30-33. (in Russian).

8. Shushkov D. A., Kotova O. B., Kapitanov V. M., Ignatiev A. N. Analcime-bearing rocks of the Timan Region as a perspective raw materials. Syktyvkar, 2006. Komi SC. V. 123.40 p. (in Russian).

9. Shushkov D., Kotova O., Shuktomova I. Removal of radionuclides by analcime-bearing rocks // IOP Conference Series: Materials Science and Engineering. 2013. V. 47. 012041.

10. Shushkov D. A., Shuktomova I. I. Sorption of radionuclides by zeolite-bearing rocks // Izvestiya of Komi Science Center of Ural Branch of RAS. 2013. № 1. Pp. 69-73. (in Russian). 